\title{
E-learning enhance the roles of teacher librarians as leadership in Collaborative Teaching and Learning
}

\author{
Wong Ngai Kuen, June \\ Vice President, Hong Kong Teacher Librarians' Association Teacher Librarian, \\ Ho Lap Primary School (Sponsored by Sik Sik Yuen) \\ Hong Kong, China \\ wongngaikuen11@gmail.com \\ Chu Wah Hing, Betty \\ Part-time tutor, HKU School of Professional and Continuing Education \\ Hong Kong, China \\ bchu05a@gmail.com
}

\begin{abstract}
Over the past 40 years, the evolution of the computer and Internet Communication Technology (ICT) has enhanced this increasingly information-driven world expanding rapidly. Once people starting to make use of Wi-Fi in communication, they can get information through their digital mobile device whenever and wherever they want. Confronting the rapid changes of ICT and the flooding of information, how to evaluate and select appropriate resources are not only the problems for the educators but also the necessary life-long learning skills for the learners. Moreover, compare with the state of the art learning resources, traditional mode of teaching and learning hardly provoke student's interest in learning. Thus traditional mode of teaching and learning would hardly stand alone and remain unchanged.

To implement e-learning, Government should not only have careful ICT planning and development. However, for the long term development, there should be sufficient funding for schools to acquire, update or upgrade all those necessary hardware and software. Besides that, for educational reforms, educators should be initiative and enthusiastic in understanding more about e-learning. Enhancing effectiveness in teaching and learning, they should think about how to incorporate targets of teaching with the resources and to make use of e-learning in provoking students' interest and initiative in learning.

Nevertheless, innovators encountered many obstacles and problems during the processes of adopting and implementing e-learning. Problems including: How to make use of mobile devices in teaching and learning? How to utilize mobile devices in facilitating learner's participation in learning activities? How to make learning and teaching more interactive? Despite all those problems, the critical one would be that most teachers were not well equipped with sufficient ICT skills. As a matter of fact, elearning would be the trend and educators could not just keep watching without taking further action. To raise the effectiveness of learning, it is important that educators should be well-equipped themselves with the necessary competences in using mobile
\end{abstract}


device and other related electronic applicants in teaching.

With our practical experience presented in this paper, we hope to share how a teacher librarian act as a leader in implementing e-learning; to elaborate the strategies promoting collaborative teaching and learning in cross-curricula; to put the roles of "Information specialist" and "Teaching partner" in practice.

Keywords: E-learning, Collaborative Teaching and Learning, Roles of teacher librarians

\section{透過電子學習計劃發揮圖書館教師推動校本協作教學的效能}

黃毅娟

朱華卿

內容撮要

在電子科技及網絡技術急速發展的近 40 年內, 資訊的流通主導社會的發展。流動電腦裝置及網 絡無處不在, 資訊垂手可得。在不斷變化、擴張的資訊科技及知識當中, 如何作出取捨, 不僅 是教育者面對的困難, 也是學子必須具備的終身學習能力。此外, 相對於電子裝置的聲光色影 的吸引力，學子對傳統的學習模式較難提起學習的興趣。因此，傳統的學習模式及內容已不能 一成不戀，教育者亦不能獨善甚身。

在推動電子學習時, 政府除了要設定資訊科技發展計劃外, 更必須投放資源於購置或更新硬件 設備、開發電子學習軟件。此外，教育者才是教育改革中最重要的主導力量，須主動、積極地 學習、思考如何善用資源, 結合教學目標及資源, 才能有效透過電子學習提升學生的學習興趣 、培養學生自主學習的態度, 從而提升學與教的成效。

事實上, 在電子教學的發展中, 推動者舉步維艱, 究其困難列舉如下: 如何在教學中運用流動 電腦裝置? 怎樣才能讓每位學生透過電子教學更有效地參與課堂學習及活動? 如何在教學中讓 學生與教師、學生與學生之間有更多互動? 在眾多問題中, 最大的問題是大部分教師缺乏足够 的資訊科技知識。然而, 電子學習將是教育的發展趨勢, 教育者不能再拭目以待, 必須主動、 積極自我增值，投入學習、思考電子學習的資訊及技能。

本文透過校本電子學習計劃經驗, 談談圖書館教師如何透過電子學習計劃推動跨科協作教學的 策略及應用, 實踐圖書館教師作為資訊專家及課程協作者的角色。

關鍵字：電子學習、協作教學、圖書館教師的角色 


\section{Introduction}

Over the past 40 years, the evolution of the computer and Internet Communication Technology (ICT) has enhanced this increasingly information-centric world expanding rapidly. When digital mobile device is linked up with Wi-Fi network, people can get information anytime anywhere. Confronting the rapid changes of ICT and the flooding of information, how to evaluate and select appropriate resources are not only the problems for the educators but also the necessary life-long learning skills for the learners. When comparing with those state of the art learning resources, traditional mode of learning and teaching is difficult to provoke students' interest in learning. Thus traditional mode of education would hardly remain unchanged. It is important that educators should always keep themselves up to date, promote E-learning, make use of mobile device in teaching and raise the effectiveness of learning.

\section{Background to the Education Reform}

In 2014, the Education Bureau of the Hong Kong SAR conducted a consultation on the Fourth Strategy on Information Technology in Education (ITE4) which focuses on realizing IT potential and unleashing the learning power of our students to learn to learn and to excel.

ITE4 aims

'to strengthen students' self-directed learning, their creativity, collaboration, problemsolving and computational thinking skills, as well as ethical use of IT in an enhanced IT environment, with schools' professional leadership and capacity, as well as the support from community partnerships.' (EDB, 2014, p.1)

In the consultation, it also pointed out the benefits of mobile technology on learning and teaching:

The popularity of mobile computing devices has brought about the Post-PC era*. Mobile technology not only enables access to various kinds of learning resources on the Internet anywhere and anytime, but also facilitates communication and interaction among students and teachers. While students can conveniently share knowledge and exchange ideas with peers, teachers can play an advisory role forging a learning partnership with students. When IT-enabled learning opportunities are readily available, students will gradually cultivate the habit of taking responsibility for their own learning and become self-directed learners. (EDB, 2014, p.6)

Referring to "Post-PC era", the document further explained (as cite in Isaacson, 2011) that

Post-PC era is a market trend that the vast majority of users will eventually adopt mobile devices, for example, smartphones and tablet computers as the primary computing device instead of personal computers. These devices emphasize portability and connectivity, including the use of cloud-based services, more focused "apps" to perform tasks, and the ability to synchronize information between multiple devices seamlessly. (EDB, 2014, p.6)

Facing the popularity of mobile technology in the post-pc era, it is important for educators to 
consider how they can make good use of those devices in order to raise the effectiveness of teaching and learning.

To implement e-learning, the Government should not only have careful ICT planning and development. However, for the long term development, there should be sufficient funding for schools to acquire, update or upgrade all those necessary hardware and software. Actually, educators are the key initiators in the educational reforms. They should be initiative and enthusiastic in understanding more about e-learning. Enhancing the effectiveness in teaching and learning, they should think about how to incorporate targets of teaching with the resources and to make use of e-learning in provoking students' interest and initiative in learning.

In fact, there are many local or international examples showing how teachers make good use of mobile technology and Internet resources to raise the effectiveness of learning and teaching. This paper aims to share the strategies and experience of how a teacher librarian makes use of the school-based e-learning program in promoting collaborative learning and teaching in cross-curricula. Besides, putting the roles of "Information specialist" and "Teaching partner" in practice in the program, teacher librarian helps to promote student's self -direct learning and enhances effectiveness of learning and teaching.

\section{Innovating an E-learning planning}

Dennie Heye is an information scientist. He emphasis

'an information professional is helping others to organize, navigate and manage information in this increasingly information-centric world with our skill set and a continuous evolution of technology, we can play a key role in companies, organisations and society.' (Heye, 2006, p.1).

As one important role of teacher librarians is information professional, teacher librarians should be an 'effective networker'. Therefore, they must always equip themselves to become key players and 'linking pins' (Heye, 2006, p.5) in the information ecology. Therefore, teacher librarian should keep us up to date, deal with the challenging in Digital Age. However, how teacher librarian can play the role as information professional and collaborate with subject teachers? This paper intends to share the practical experiences in a primary school in Hong Kong and to show how teacher librarian as an information professional in E-learning to promote Collaborative Teaching and Learning.

Last year, we joined two E-learning projects. The first one was supported by Quality Education Fund (QEF) of Education Bureau. The project title was 'Strengthening students' reading comprehension ability (both Chinese and English) through developing children's literature e-quiz bank on cloud'. The other one was New Learning Experience (NLE) projects. Samsung tried to recruit some schools to join the Samsung Smart School to promote E-learning in June. Our school had been selected by NLE project. The project topic was 'SMART SCHOOL: Library Co-operation E-learning in the M Generation'. Samsung provided 37 tablets for our schools. Most of all teachers involved in this project for cooperative teaching to promote E-learning. 
The project tried to combine old ideas in a new way which had been the main driver for the innovation. In addition, new idea or service turned out when the project was in progress.

\section{The details of the "SMART SCHOOL" E-learning project}

Aims of E-learning project

This "SMART SCHOOL: Library Co-operation E-learning in the M Generation" E-learning project intended to adopt mobile devices in teaching and learning to provide more interactions between teachers and students; to arouse students' interest of reading through activities; to raise students' reading and comprehending ability by taking part in the competition and completing the assessments from 'cloud' platform; to motivate self-directed learning through multimedia, interactive mode of learning and teaching; and to design and plan collaboratively for the strategies in developing knowledge-based IT education. Besides teaching students to master their competence in multimedia resource based learning, teachers also helped them to develop the appropriate behaviour in using ICT.

\section{Creativity project: Old ideas in a new way}

Adopting mobile devices in lessons, teaching materials had to be revised and adjusted before they could be used in e-learning. Such mode of learning and teaching motivated students' interest in learning and provided more interactions between student and teacher, student and student. It helped to develop students' initiative in learning. The collaborative planning and teaching (CPT) in e-learning enhanced teachers' professional development. From the observation during the processes of the implementation, teachers identified the impacts of e-learning. On the other hands, it facilitated teachers' professional development of E-learning.

With light to carry and convenient to use tablets, students could access the learning materials wherever Wi-Fi is found. Furthermore, they could easily write and draw on the touch screen of the tablets, this solved the problems for those who were not skillful in Chinese character input. Although there were only thirty-seven tablets available, the tablets provided ample opportunities for students in e-learning and provoked their interest in learning. Through the 'Cloud' platform, students could develop self-directed learning in their own time and speed; they could learn from peers and had better understanding of their own learning. Thus, E-learning program could also cater individual learning differences.

\section{Mission of education: Develop mobile device to enhance learning and creativity.}

Facing the challenge in the e-learning, the priority consideration is to change the traditional mode of education that the educators ever had. Educator's confidence of using e-learning and their skill of using it would be interrelated. Nevertheless, educators should recognise that e-learning is necessary and they should be energetic, innovative in adopting those new technologies in teaching and learning if they want to foster self-directed learning and creativity in learning.

\section{Tasks in e-learning program}




\begin{tabular}{|c|c|c|c|}
\hline Class & Activities & $\begin{array}{l}\text { People who take } \\
\text { part in CPT with } \\
\text { teacher librarian }\end{array}$ & Learning task \\
\hline P.1 & E-library & Class teacher & Online reading and voting \\
\hline P.2 & E-library & Class teacher & Online reading and voting \\
\hline P.3 & "Cloud" project & $\begin{array}{l}\text { Chinese language } \\
\text { teacher }\end{array}$ & E-quest and book promoting \\
\hline \multirow[t]{2}{*}{ P.4 } & "Cloud" project & $\begin{array}{l}\text { English and } \\
\text { Chinese language } \\
\text { teacher }\end{array}$ & E-quest and book promoting \\
\hline & Drama & $\begin{array}{l}\text { Chinese language } \\
\text { and drama teacher }\end{array}$ & Drama script writing \\
\hline \multirow[t]{4}{*}{ P.5 } & "Cloud" project & $\begin{array}{l}\text { English and } \\
\text { Chinese language } \\
\text { teacher }\end{array}$ & E-quest and book promoting \\
\hline & $\begin{array}{l}\text { A trip to meet the } \\
\text { famous scientists }\end{array}$ & General science & $\begin{array}{l}\text { E-quest, } \\
\text { use GPS to display the route and } \\
\text { tasks, practice the internet } \\
\text { searching skill }\end{array}$ \\
\hline & $\begin{array}{l}\text { Reading strategy: } \\
\text { Newspaper reading }\end{array}$ & Class teacher & Skimming and assessment \\
\hline & Famous people show & $\begin{array}{l}\text { Chinese language } \\
\text { and drama teacher }\end{array}$ & Drama script writing \\
\hline \multirow[t]{2}{*}{ P.6 } & $\begin{array}{l}\text { Reading club: Bring } \\
\text { Characters alive }\end{array}$ & $\begin{array}{l}\text { Art and Craft } \\
\text { teacher }\end{array}$ & $\begin{array}{l}\text { Reading in depth, sharing and } \\
\text { drawing }\end{array}$ \\
\hline & E-library & Class teacher & Online reading and assessment \\
\hline
\end{tabular}

Table 1.

\section{Strategies of adopting tablets in learning and teaching}

Facing new things, adults usually feel uneasy or worry too much. They tend to keep things unchanged instead of accepting new ideas. On the contrary, our students are curious to explore new things. Thus they are smart in learning to use any electronic devices. Actually, the development of electron devices tends to be more user friendly. As long as we make good use of electronic teaching resources and technology, maintaining the status quo, it is possible for us to input new concepts into the existing teaching materials. Furthermore, to enrich our teaching materials, we can combine resources from Internet. At the same time, mode of teaching can be changed to student-centered, interactive and self-directed learning 
mode. In addition, this mode of learning will reduce the burden comes from traditional knowledge teaching mode and it also raise the effectiveness of learning. Through the application of school-based e-learning experience, the commonly used e-learning strategies and technology are as follows:

Internet:

- Browse the web

- Quiz

- Browse Videos (Youtube)

- Vote

- Discussion, recording, photo taking, video

- Use Google cloud platform to share documents, Google sites for communication and collaborative writing.

Classroom management systems: Samsung School Class mode

- Student monitoring

- Send and receive files

- Other computer program (Apps): Mobile School (BEYOND CAMPUS)

This project utilized mobile devices in lessons for all students from Primary 1 to Primary 6 . Firstly, we promoted E-library to Primary 1 and Primary 2. Instead of lengthy typing, QR code was used for helping them searching. Students were taught to search E-books and read E-books.

For primary 6 students, Teacher librarian had collaborative teaching with Visual Art teachers. Reading Club during library lesson engaged students discussing the characters of a book "Oscar and the Lady in Pink". Additional online reading materials and videos related to "Life Education' was given. Students were required to read this novel and the additional information. They were guided to think about the meaning of a life. At last, based the understanding about the 'Oscar and the Lady in Pink', students were guided by Visual Art teacher to choose a character and draw a picture of the character. The discussing results, assignment, mind map products and teaching resources would be uploaded onto a google site to stimulate students self-learning. Through reading printing book, online news and videos, students organized, navigated and managed different kinds of information of a topic and created a new learning product.

For primary 3 to primary 5, Chinese and English language teachers planned and taught collaboratively. We had another project named 'Strengthening Students' Reading Comprehension Ability (both Chinese and English) through Developing Children's Literature E-quiz Bank on the Cloud" (Cloud Project). This project is supervised by the Principal investigator (PI), Dr. Samuel Kai Wah Chu who is an Associate Professor of Faculty of Education and the Deputy Director of the Centre for Information Technology in Education of the University of Hong Kong. This proposed project aims to strengthen reading comprehension ability of Hong Kong primary school students through engaging in an interactive e-quiz cloud service as post-reading activities to monitor students' level of comprehension in children's literature. Collections of quality children's literature are selected from award winning books. A bank of during-reading and post-reading questions (with scaffolding support) specific to each title is developed by the project team with input from 
participating teachers. The e-quiz cloud service is accessible via a web browser or via a software application for mobile devices.

\section{Innovational curriculum: the roles of teacher librarian as information professional}

"That innovation and creativity can lead to new and exciting tools and services. In addition, it is not just about us creating new tools and creating services, as information professionals we can also help our organizations in supporting innovation..."

When the project was in the processing, we needed new ideas or service to solve the problems of lacking interaction with students. We started to develop innovative curriculum to satisfy the requirement of interactive learning and teaching.

In English subject teaching scheme of work of primary 4, there is a reader named "Eating around Hong Kong". This book is included in the "Cloud Project". Teacher librarian searched and located all related teaching materials in school and from webs. Teacher librarian adopted the questions of e-quiz cloud from project team. English teacher based the contents of story book to re-allocate the sequence of questions. To implicate the E-learning, teacher librarian provided the new idea and service including an online question form from Google Earth Platform which is an excellent innovative information management tools. Beside, educational software, "Edmodo" was a good platform to group the students in one class. Students logon the platform to finish the tasks such as taking pictures, sound recordings, discussing and sharing documents. Teacher librarian taught them the technologies of the software in library lessons.

In addition, teacher librarian used the document function of Google Earth Platform to support Chinese subject teachers and drama teachers in writing assignment. Teacher librarian guided the primary 4 and 5 students to develop a drama transcript on google drive; engaged students using tablets to collaborative learning and writing. Teacher librarian also organised a reading competition in which students read biographies of famous scientist in depth. The questions were created by General Science teachers. Then students participated in an Equest, a reading competition by using GPS to display the route and tasks, hence students practiced the internet searching skill by using tablets. The software of "Beyond Campus" and "EduVenture" platform, designed by IT department of EDB and Centre for the Advancement of IT in Education of Chinese University of Hong Kong respectively, can be used for planning outdoor interactive activities.

\section{Conclusion}

The Hong Kong Government will launch The Fourth Strategy on IT in Education (ITE4) in 2015. Major proposed initiatives include the phased provision of wireless network services and other supporting facilities for all public sector schools. However, most teachers are not yet ready in adoption IT in teaching.

Nevertheless, innovators encountered many obstacles and problems during the processes of adopting and implementing e-learning. Problems including: How to make use of mobile devices in teaching and learning? How to utilize mobile devices in facilitating learner's participation in learning activities? How to make learning and teaching more interactive? 
Despite all those problems, the critical one would be that most teachers were not well equipped with sufficient ICT skills. As a matter of fact, e-learning would be the trend and educators could not just keep watching without taking further action. To raise the effectiveness of learning, it is important that educators should be well-equipped themselves with the necessary competences in using mobile device and other related electronic applicants in teaching.

From the E-learning project experience, this mode of learning enhanced the roles of teacher librarians as information professional and leadership in Collaborative Teaching and Learning. 'Being an information professional, however, requires certain characteristics to transform successfully into twenty-first century information professional, constantly reinventing themselves to stay relevant' (Heye, 2006). Teacher librarians, who are information professional, should be an active learner and effective networker. Therefore, teacher librarians should always be ready to become the key players and 'linking pins' in the information ecology when the education reform is in processing. 


\section{透過電子學習計劃發揮圖書館教師推動校本協作教學的效能}

黃毅娟

朱華卿

前言

在電子科技及網絡技術急速發展的近 40 幾年內, 資訊的流通主導社會的發展。時致今日, 流動 電腦裝置及網絡無處不在, 資訊垂手可得。在不斷變化、擴張的資訊科技及知識當中, 如何作 出取捨, 不僅是教育者面對的困難, 也是學子必須具備的終身學習能力。此外, 相對於日常生 活中電子裝置的聲光色影的吸引力, 學子對傳統的學習模式較難提起學習的興趣。因此, 傳統 的學習模式及內容已不能一成不變, 教育者亦不能獨善甚身。教育者必須肯定電子學習的重要 性，與時俱進，提升自己的電子教學能力，應用流動電腦裝置提升學與教的成效。

\section{教育改革的背景}

當前, 教育局開始推展第四個資訊科技教育策略諮詢文件(Fourth Strategy on Information Technology in Education, ITE4)。第四個資訊科技教育策略以學生學習為中心，ITE4的目標 是:

$\ulcorner$ 以“發揮IT潛能，釋放學習能量” 為題，旨在透過發揮資訊科技的潛能，提升學與教的互動經 驗，以釋放學生的學習能量，讓學生學會學習、邁向卓越。透過優化的資訊科技環境，發揮學 校的專業領導與能力，加上社區夥伴的支援，從而加強學生的自主學習、創意、協作及解難能 力，並提升他們的計算思維技巧及使用資訊科技的操守。」

(教育局, 2014, p.1)

這份咨詢文件指出應用流動電子裝置於學與教的好處：

流動電腦裝置的普及引領我們進入後電腦時代*，流動科技不單能讓學生隨時隨地從互聯網上 得到各種學習資源, 也能促進師生間的溝通及互動。學生能便捷地與同儕及老師分享知識及交 流意見，而教師亦可扮演顧問的角色，與學生建立學習夥伴的關係。當資訊科技衍生的學習機 會增加，學生會逐漸培養對個人學習負責的態度及習慣，進而成為自主學習者。

(教育局, 2014, P.6)

ITE4諮詢文件(引述 Isaacson, 2011)指出：

後電腦時代是一種市場趨勢, 大部分用家最後會選用流動裝置如智能電話及平板電腦等, 取代 個人電腦成為首要的電腦裝置。這些裝置著重便攜和連接性，包括雲端服務的使用、更專門的 應用程式以執行任務，以及在多種裝置之間同步而無縫地處理資訊。

(教育局, 2014, P.6)

面對後電腦時代，教育者目前最需要思考的是如何善用流動電腦裝置以提升教學成效。 
在推動電子學習時, 政府除了要設定資訊科技發展計劃外, 更必須投放資源於購置或更新硬件 設備、開發電子學習軟件。此外, 教育者才是教育改革中最重要的主導力量, 須主動、積極地 學習、思考如何善用資源, 結合教學目標及資源, 才能有效透過電子學習提升學生的學習興趣 、培養學生自主學習的態度, 從而提升學與教的成效。

事實上, 本地及國際有不少個案讓我們見證教師如何善用流動科技及互聯網的資源, 提升學與 教的成效。本文透過校本電子學習計劃經驗, 談談圖書館教師如何透過電子學習計劃推動跨科 協作教學的策略及應用，實踐圖書館教師作為資訊專家及課程協作者的角色，從而推動學生自 主學習及提升學與教的成效。

\section{電子學習新體驗}

Dennie Heye 是一位資訊科學家。他強調:

一位資訊專家是在不斷增長的資訊中心，運用技巧、持繼演變的科技幫助別人去組織、行駛及 管理資訊，成為一間公司、機構和社會中的重要角色。

作為圖書館教師，其中一個重要的角色是成為一位資訊專家。在不斷增長的網絡資訊世界，圖 書館教師作為資訊的管理員, 必須是精通網絡技能的。因此, 圖書館館教師必須自我增值, 應 對信息迅變的時代。但是，圖書館教師如何才能透過跨科協作教學體現資訊專家的角色呢 ? 接 下來介紹的是香港小學圖書館教師於校本跨科電子協作教學的計劃及工作經驗。

2014年至今, 本校先後參與兩份電子學習計劃。首先是由香港教育局的「優質教育基金」資助 的「透過雲端兒童文學讀後測驗庫服務加強學生的中、英文閱讀理解能力」(雲端計劃); 然後 , 本校成功申請了「三星智能教學新體驗平板電腦試驗計劃」(三星計劃), 計劃名稱是 $「$ 優質 校園：圖書館在M世代支援學科教學的協作計劃」(優質校園)。主辦機構三星免費提供37部平

\section{板電腦讓學校推行電子教學。}

結合兩項計劃, 本校進行了圖書館跨科協作教學, 推動電子教學計劃。這個計劃重組舊的教學 活動, 以新的電子教學模式重新展示出來。同時, 圖書館的服務也因此有重大的改變。

\section{三星智能教學新體驗計劃的詳情}

\section{目標}

本計劃「優質校園：圖書館在M世代支援學科教學的協作計劃」(「優質校園」)的目標以平板 電腦作為媒介，增加師生進行互動學習的機會。雲端計劃希望透過活動提高學生中英文的閱讀 興趣; 亦希望透過雲端題目庫測試及比賽, 提高學生中英文閱讀理解能力。老師需要設計多元 化的電子教學教案，推動學生自主學習。透過跨科教學活動，教師團隊協力設計及實施以知識 為本及資訊科技教學的策略。除了教導學生更好地掌握多媒體資源的學習技能外，教師同時亦 
教導學生使用多媒體的正確態度。

\section{新、舊意念結合的創新計劃}

透過使用平板電腦，使很多教材重新整理後，以電子科技展示於學生面前，提高了學生學習的 興趣及增加了學生與教師、學生與學生之間的分享、交流及互動，增加了學生學習的主動性。 而協作教師在協作過程中，透過觀察，發現電子教學的效益，主動參與及學習，促進了教師的 專業發展。

平板電腦便於携帶, 無線網絡、繪畫及書寫功能, 亦解決了學生在學習上紀錄及交流時未能掌 握電腦中文輪入法的困難。雖然只有37部平板電腦, 但是全校學生於電子教學都能受益、增加 了學習的樂趣，使學習跨越空間的界限，讓學生可以透過雲端科技及網站自主學習、方便教師 展示學習的成果、同齊學習及照顧個別差異。

\section{教育信念：發揮資訊科技的力量促進電子學習的影響力與創意空間}

在面對教育改革中電子教學的衝擊中, 首當其衝的困難是要改變教育者的傳統教育觀念。教育 者是否有足够的信心進行電子教學與運用資訊科技的能力是互相影響的。因此，教育者必須先 認同電子教學的必須性、重要性, 還要有幹勁, 自我增值, 求新求變的決心, 便能發現及發揮 電子高科技促進學習的影響力, 發揮電子學習的創意空間。

\section{電子教學的實踐項目}

\begin{tabular}{|c|c|c|c|}
\hline 年級 & 主要活動内容 & 與圖書館協作教學人員 & 電子教學項目 \\
\hline 一 & 電子圖書館 & 班主任 & 網上閱讀及投票 \\
\hline 二 & 電子圖書館 & 班主任 & 網上閱讀及投票 \\
\hline 三 & 雲端計劃 & 中文科 & 答問比賽及推介圖書 \\
\hline \multirow[t]{2}{*}{ 四 } & 雲端計劃 & 英文科、中文科教師 & 答問比賽及推介圖書 \\
\hline & 童話劇場 & 中文科、戲劇科教師 & 寫作劇本 \\
\hline \multirow[t]{2}{*}{ 五 } & 雲端計劃 & 英文科、中文科教師 & 答問比賽及推介圖書 \\
\hline & 世界名人成功之旅 & 常識科 & $\begin{array}{l}\text { 網上問答比賽、 } \\
\text { 戶外衛星定位(GPS)確定 } \\
\text { 學習路線及實習網上搜索 } \\
\text { 資料的技能 }\end{array}$ \\
\hline
\end{tabular}




\begin{tabular}{|l|l|l|l|}
\hline 年級 & 主要活動内容 & 與圖書館協作教學人員 & 電子教學項目 \\
\hline \multirow{2}{*}{ 六 } & 閱讀策略: 閱讀報章 & 班主任 & 速讀體驗及評估 \\
\cline { 2 - 4 } & 世界名人SHOW & 文中科、戲劇科教師 & 寫作劇本 \\
\hline & 「活現書中人」讀書會 & 視㙯科教師 & $\begin{array}{l}\text { 深度閱讀、分享及繪畫劇 } \\
\text { 中人物 }\end{array}$ \\
\cline { 2 - 4 } & 電子圖書館 & 班主任 & 網上閱讀及評鑑網頁 \\
\hline
\end{tabular}

平板電腦在教與學的應用策略

對於陌生的事物, 我們心存忌憚, 太多顧慮, 所以成人容易墨守成規, 不太容易接受新事物。 相反, 學生因為好奇心，在電子科技的學習及運用方面，卻是一點就明。為了更貼近電子媒介 充斥日常生活的社會環境, 推動以電子科技進行學習的方式勢在必行。實際上, 資訊科技應用 程式的發展以方便、簡易為原則, 沒想像中困難。而且, 只要我們善用電子教學資源及技術, 以不變應萬變, 則可以新的概念優化舊有的教材, 更可以結合網絡學習資源, 豐富教材, 與此 同時, 教學模式便可以轉變為以學生為中心的互動、自主學習模式，同時也可減輕傳統單向傳 授知識的教學負擔, 提升的學與教的成效。透過校本電子教學的應用經驗, 以下為常用的電子 教學策略及可應用的電子教學技術或程式:

上網:

*瀏覽網頁

*問答、測驗

*瀏覽影片(Youtube)

*投票

*討論、錄音、影相、錄影

*利用Google雲端共享文件、協作平台進行交流及協作寫作教學

課堂管理係統: Samsung School Class mode

學生監控

收發文件

其他電腦程式(Apps)：移動學堂 (BEYOND CAMPUS)等

本計劃惠及全校學生。首先, 圖書館主任與班主任協作，向一至二年級學生推介電子圖書館。 學生運用平板電腦, 以「QR Code」簡易的方法登入電子圖書館的網頁。學生學習利用平板電 腦搜尋電子圖書及閱讀圖書。

為六年級安排的活動是生命教育讀書會：活現書中人。圖書館教師與視藝科教師合作進行這活 動。圖書館教師在圖書課引導學生閱讀及討論《最後12天的生命之旅》的內容及書中不同角色 的性格、特點，延伸閱讀或觀看與生命教育有關的剪報及影片。教師透過引導學生討論，讓學 生深入明白生命的意義。在此基礎上，視藝科教師引導學生欣賞畢加索的作品，學生選擇書中 
的一個角色, 模仿畢加索的繪畫技巧, 創作故事人物的畫像。而圖書課堂上要求學生做的討論 結果, 包括腦圖、簡報、感想和教學簡報, 還有過往學生的優秀作品, 都上傳於谷歌協作平台 網頁上展示, 鼓勵學生重溫學習內容、自學新的知識。活動透過閱讀印刷書本, 再加上網上新 聞和影片，學生重組不同的學習材料，再創造新的作品。

此外, 以三至五年級為主要推介對像的雲端計劃是整個三星協作計劃的主導活動。目的是推 動三至五年級學生透過電子學習, 提升中、英文理解能力。計劃促使中、英文科任教師必須與 圖書館主任協作，推動閱讀。計劃的負責人是香港大學朱啟華博士。「透過雲端兒童文學讀後 測驗庫服務加強學生的中、英文閱讀理解能力」計劃的目標是透過雲端測驗庫加強香港小學中 英文理解能力。計劃包括的優質兒童文學中, 大部分是獲獎書籍。由資深教師根據書本內容出 題。透過上網及流動電腦裝置便可以登入使用雲端題目庫。成效可透過圖書館的借閱數據及教 師的觀察所知; 雲端計劃推介的有趣的兒童文學吸引學生閱讀, 從而引領學生從閱讀簡單的故 事過度到閱讀內容較深、多文字的書籍; 雲端計劃中的「閱讀大挑戰」平台讓學生從閱讀中獲 得成功感, 從而鼓勵學生自我挑戰, 主動參與, 提升閱讀量及加深對圖書內容的深入理解。

革新的課程：圖書館教師作為資訊專家的角色

$\ulcorner$ 改革與創意可以引領我們獲得全新和令人興奮的工具和服務。此外，這不僅使我們創造出新 的方法和服務，作為資訊專家，我們亦可以透過這個方法及服務去支援我們的機構進行改革 \lrcorner$($ Heye, 2006)

當計劃開始後, 我們需要新的構思和服務去解決如何透過流動電腦配置進行互動教學的問題。 我們開始去發展互動電子教學的需求。

在四年級英文科課程中有一本必讀書是「Eating around Hong Kong」。這本書是雲端計劃其 中一本書。圖書館教師為學科教師獲取一個支援教學的資源：題目庫。英文教師根據圖書內容 把題目分成三部分。此外, 為了推動電子教學, 圖書館教師提供了教學新建議及服務, 包括為 教師設立網上題目問卷。同時, 教育平台「Edmodo」也是一個非常好的教育平台, 教師可以 為學生建立小組平台，讓同一班學生登入並在平台上完成教師指定的作業，例如照相、錄音、 討論及分享文件。圖書館教師利用圖書課教導學生使用平台的技能。

另一方面, 圖書館教師利用谷歌文件共享的功能去支援中文科、戲劇科教師, 讓學生在圖書館 課創作劇本。透過文件共享的功能，學生可以同時修訂同一份文件的內容，讓學生與學生之間 有更多互動學習的機會。圖書館教師也和常識科教師協作，進行「世界名人成功之旅」名人傳

記閱讀比賽。每位常識科教師推介一本名人傳記並設五條問題交給圖書館教師。學生除了可上 網回答名人問題外，圖書館教師還利用「移動學堂」(Beyond Campus)，透過全球定位系統 (Global Positioning System, 通常簡稱GPS)，學生需要利用平板電腦先搜索遊戲區，然後學生 可實習利用網上搜索技巧尋找答案，再回答問題。「移動學堂」是由教育局研發製作的電子教 學工具。與「移動學堂」類似的戶外學習軟件還有「戶外移動學習系統」(EduVenture)平台。 


\section{這平台是由香港中文大學資訊科技教育促進中心設計及管理。}

\section{總結}

今年，教育局將推展第四個資訊科技教育策略諮詢文件(Fourth Strategy on Information Technology in Education, ITE4)。計劃主要為學校提供網絡服務及構買流動電腦裝置的資助。 但是, 大部分的教師還没有做好投入電子教學的準備。

即使電子教學的成效有目共睹, 電子技術的硬件軟件萬事具備, 在校本電子教學的發展中, 推 動者還是舉步維艱, 回顧困擾教師有關電子教學的問題列舉如下: 如何在教學中運用流動電腦 配置? 怎樣才能讓每位學生透過電子教學更有效地參與課堂學習及活動？如何在教學中讓學生 與教師、學生與學生之間有更多互動? 在眾多問題中, 最大的問題終究是大部分教師現有的工 作量繁重、缺乏足够的資訊科技知識。然而, 電子學習將是教育的發展趨勢, 教育者不能再拭 目以待, 必須主動、積極自我增值, 投入學習、善用電子教學的資訊及技能, 透過電子學習減 少教育者的教學重擔。

透過校本電子學習計劃經驗, 圖書館教師作為資訊專家, 可透過電子學習計劃推動跨科協作教 學。「一位資訊專家必須俱備一些特質使自己成功過度為21世紀的資訊專家，這就需要我們持 續作出相關的改變」(Heye, 2006). 作為圖書館教師, 我們必須是主動學習者及提升自己資訊 科技的能力, 才能在電子教學改革中, 從起點對教師提供建議及協助, 實踐圖書館教師作為資 訊專家及課程協作者的角色, 從而推動學生自主學習及提升學與教的成效。

\section{References}

Assessment and Teaching of 21st Century Skills. (2010). What are 21st-Century Skills? http://atc21s.org/index.php/about/what-are-21st-century-skills/, accessed March 2015).

Cooper, Hilary. (2013). Teaching History Creatively. UK: Routledge.

Curriculum Development Council. (1999). A Holistic Review of the Hong Kong School Curriculum: Proposed Reforms Consultative Document. Hong Kong: Curriculum Development Council.

Curriculum Development Council. (2001). Learning to Learn: The Way Forward in Curriculum Development. Hong Kong: Curriculum Development Council http://www.e-c.edu.hk/eng/reform/index e.html

Education Commission. ( 2000). Learning for Life, Learning through Life: Reform Proposals for the Education System in Hong Kong. Hong Kong: Printing Department.

Education Bureau of the Government the HKSARG (2011). Press Release on Hong Kong students' performance in digital reading literacy in the Programme for International Student Assessment (PISA) 2009.

http://www.info.gov.hk/gia/general/201106/28/P201106280254.htm 
Education Bureau of the Government the HKSARG (2014). Consultation on the Fourth Strategy on Information Technology in Education.

http://www.edb.gov.hk/attachment/en/edu-system/primary-secondary/applicable-toprimary-secondary/it-in-edu/it-in-edu/Policies/4th consultation eng.pdf , accessed March 2015.

Heye,Dennie Heye. (2006). Characteristics of the Successful Information Professional. UK: Chandos Publishing.

課程發展議會編定 (2002)。基礎教育課程指引一各盡所能．發揮所長(小一至中三)。香港 : 教

育局課程發展處。http://www.edb.gov.hk/tc/curriculum-development/doc-reports/guide-basicedu-curriculum/index.html accessed March 2015).

課程發展議會編定 (2014)。基礎教育課程指引一聚焦．深化．持續(小一至小六)(2014)。香港 : 教育局課程發展處。 